\title{
EVALUATION OF IN VITRO HEPATIC TOXICITY OF LEAVES OF PTEROSPERMUM ACERIFOLIUM (L.) WILLD.
}

\author{
RANA DATTA ${ }^{1}$, SANKHADIP BOSE ${ }^{2}$, SUDIP KUMAR MANDAL ${ }^{3 *}$
}

${ }^{1}$ Department of Pharmacology, Gupta College of Technological Sciences, Asansol, West Bengal, India. ${ }^{2}$ Department of Pharmacognosy, Bengal School of Technology, Hooghly, West Bengal, India. ${ }^{3}$ Department of Pharmaceutical Chemistry, Faculty of Pharmacy, Dr. B. C. Roy College of Pharmacy and Allied Health Sciences, Bidhannagar, West Bengal, India. Email: gotosudip79@gmail.com

Received: 31 January 2020, Revised and Accepted: 18 March 2020

ABSTRACT

Objective: The objective of the study was to determine the in vitro hepatic toxicity profile of methanolic extract of leaves of Pterospermum acerifolium (L.) Willd. (MEPA) using a mammalian hepatic cell line (HepG2).

Methods: To assess its in vitro hepatic toxicity, 3-(4,5-dimethylthiazol-2-yl)-2,5-2,5-diphenyltetrazolium bromide assay using MEPA at a concentration of $25 \mu \mathrm{g}, 50 \mu \mathrm{g}, 100 \mu \mathrm{g}, 200 \mu \mathrm{g}$, and $300 \mu \mathrm{g}$ was carried out. Sorafenib tosylate was used as the standard agent to assess cytotoxicity.

Results: The inhibitory concentration $50\left(\mathrm{IC}_{50}\right)$ value for HepG2 cell lines was determined after 24 h. Thereafter the cytotoxicity study was again performed with the $1 / 2 \mathrm{IC}_{50}, \mathrm{IC}_{50}$, and $2 \mathrm{IC}_{50}$ doses of MEPA. Experimentally, the $\mathrm{IC}_{50}$ was found to be $150.42 \mu \mathrm{g} / \mathrm{ml}$ for HepG2 using MEPA. A dosedependent cytotoxicity and reduction in optical density were also observed with incremental MEPA administration.

Conclusion: The cytotoxic potential of MEPA was found to be much less than that of sorafenib tosylate. Thus, MEPA shows in vitro cytotoxicity in mammalian hepatic cells (HepG2) at a concentration as low as $100 \mu \mathrm{g}$.

Keywords: Pterospermum acerifolium, Cytotoxicity, In vitro, Cell line, Hepatocarcinoma.

(C) 2020 The Authors. Published by Innovare Academic Sciences Pvt Ltd. This is an open access article under the CC BY license (http://creativecommons. org/licenses/by/4. 0/) DOI: http://dx.doi.org/10.22159/ajpcr.2020.v13i5.36998

\section{INTRODUCTION}

Demand for herbal medicine has increased tremendously in recent years; however, there many issues regarding their safety. Very less $(<10 \%)$ marketed herbal products are actually standardized. Furthermore, quality control measures are not followed on many occasions [1]. Even in the literature, very little toxicological information is available. Since some plants produce toxic constituents for defense purposes, it becomes absolutely necessary to explore the safety profile of herbal drugs. The plant Pterospermum acerifolium (L.) Willd., belonging to the family Sterculiaceae, is used by the tribals of Chotanagpur, Konkan, and Arunachal Pradesh region of India, for the treatment of different diseases such as wound healing and hemostatic activities $[2,3]$.

However, no toxicological data are available for the plant. Preliminary phytochemical studies showed the presence of alkaloids, flavonoids, and glycosides in the methanolic extract of $P$. acerifolium (L.) Willd. (MEPA). Conventionally, the presence of alkaloids has been implicated to cytotoxicity; thus, it is worth to elucidate the toxicological profile of MEPA both from therapeutic and toxicological standpoint. Herbal medicines are normally considered safe, but chronic administration may lead to cumulative toxicity. Thus, it is equally important to evaluate P. acerifolium (L.) Willd. for its toxicological profile.

In vitro toxicity testing is frequently done on mammalian hepatic cell line HepG2 [4]. HepG2 through a cancer cell line is frequently used to assess in vitro toxicity. It was first derived from a 15-year-old Caucasian American male. In vitro studies offer additional advantages over the traditional animal models on many aspects. It allows a species-specific, simpler, and more detailed analysis [5]. In vitro studies, if designed well, can very well replace whole animal studies in days to come.

The present study was undertaken to elucidate the in vitro toxicological implications (if any) on HepG2 cell lines, to establish the safety profile of MEPA.

\section{METHODS}

\section{Preparation of extracts}

The leaves of $P$. acerifolium were collected from Asansol, West Bengal, in the month of September 2013 and 2014 at 11 a.m. The plant was identified and authenticated as P. acerifolium (L.) Willd. by the Director, Acharya Jagadish Chandra Bose Indian Botanic Garden, Shibpur, Howrah, India. The leaves of $P$. acerifolium were dried in the shade of about $30^{\circ} \mathrm{C}$ and crushed into a coarse powder.

\section{Cell culture}

Hepatocellular carcinoma cell line HepG2 was purchased from National Facility for Animal tissue and cell culture, Pune, India, and supplied from Indian Institute of Chemical Biology for in vitro studies. Hepatoma cells were subcultured after every 2 days at an initial concentration of $1 \times 10^{6}$ cells $/ \mathrm{ml}$ and maintained in sterile Dulbecco's Modified Eagle Medium (DMEM) supplemented with 10\% heat-inactivated fetal calf serum [5]. The culture was maintained at $37^{\circ} \mathrm{C}$ in a humidified atmosphere containing $5 \% \mathrm{CO}_{2}$ in the air [6]. During subculturing or during the use of HepG2 in experiments, this adherent property has been diminished by adding $\times 1$ Trypsin solution in the cell [7]. In all the experiments, untreated hepatic cells were used as a control group.

\section{Preparation and extraction of the tested plant sample}

Leaves of P. acerifolium (L.) Willd. were air-dried in the shade. The dried leaves were extracted with methanol, were crushed, and then extracted by continuous hot extraction process for $72 \mathrm{~h}$ in Soxhlet apparatus, using a reflux condenser. Then, the solvent was removed by filtration. Fresh solvent was added and further extracted for $3 \mathrm{~h}$. The extract was concentrated by vacuum under reduced pressure. Thereafter, the extract was lyophilized for $4 \mathrm{~h}$ to produce methanol free extract. It was kept in a container, sealed with parafilm and stored at $4^{\circ} \mathrm{C}$ in an airtight container, and was designated as MEPA. Stock solution was prepared as $1 \mathrm{mg} / \mathrm{ml}$ in phosphate buffer saline (PBS) from which desired doses were tested. 
Preliminary phytochemical studies

Preliminary phytochemical studies showed the presence of alkaloids, flavonoids, and glycosides in the MEPA.

Cytotoxicity study by 3-(4,5-dimethylthiozol-2-il)-2,5-2,5dipheniltetrazoliumbromide (MTT) assay

Cytotoxicity studies after trypsinization of HepG2 cells $\left(1 \times 10^{5}\right), 100 \mu \mathrm{l}$ cell suspension per well in a log phase were seeded in 96 well tissue culture plates. They were treated with MEPA freshly prepared $1 \mathrm{mg} / \mathrm{ml}$ stock solution in a concentration of $25 \mu \mathrm{g}, 50 \mu \mathrm{g}, 100 \mu \mathrm{g}, 200 \mu \mathrm{g}$, and $300 \mu \mathrm{g}$ for 24,48 , and $72 \mathrm{~h}$ at $37^{\circ} \mathrm{C}$ in a humidified atmosphere containing $5 \% \mathrm{CO}_{2}$ in the air. Untreated cells served as control. Sorafenib tosylate was used as a standard [8]. At the end of treatment, in the respective time, the media from the upper layer have been removed; then again, $100 \mu \mathrm{l}$ DMEM media was added. Then, $20 \mu \mathrm{l}$ of MTT ( $5 \mathrm{mg} / \mathrm{ml}$ in PBS) as a stock solution was added to each well and incubated for another $4 \mathrm{~h}$ [9]. The MTT assay is a colorimetric assay for measuring the activity of enzymes that reduce MTT to formazan dyes, giving a purple color [4]. A solubilization solution dimethyl sulfoxide $100 \mu \mathrm{l}$ was added to dissolve the insoluble formazan product into a colored solution $[10,11]$. The absorbance was taken at $570 \mathrm{~nm}$ by microplate manager (Reader type: Model 680 XR Bio-Rad Laboratories Inc.) inhibitory concentration $50\left(\mathrm{IC}_{50}\right)$ value for HepG2 cell line was determined after $24 \mathrm{~h}$. The $\mathrm{IC}_{50}$ value was determined (for the cell lines) and the cytotoxicity study was again performed using $1 \frac{1}{2} \mathrm{IC}_{50}, \mathrm{IC}_{50}$, and $2 \mathrm{IC}_{50}$ doses.

\section{Statistical analysis}

Statistical analysis was done by Student's t-test. $\mathrm{p}<0.05$ was considered as statistically significant.

The percentage cell inhibition was calculated by the following formula: $\%$ Cell inhibition $=[\mathrm{OD}$ of control $-\mathrm{OD}$ of treated $] / \mathrm{OD}$ of control $] \times 100$

$$
\mathrm{OD}=\text { Optical density }
$$

The percentage cell viability was calculated by the formula:

Viable cells $(\%)=($ Total number of viable cells per $\mathrm{ml} /$ Total number of cells per $\mathrm{ml}) \times 100$

\section{RESULTS}

MEPA at concentrations of $100 \mu \mathrm{g}, 200 \mu \mathrm{g}$, and $300 \mu$ g significantly ( $<<0.05)$ inhibited the growth of HepG2 cells compared with that of the control cells after 24,48 , and $72 \mathrm{~h}$ of treatment in a concentration-dependent manner (Fig. 1). In the MTT assay, there was a significant $(\mathrm{p}<0.05)$ concentrationdependent reduction in the OD values after treating the HepG2 cells with the same concentrations of MEPA for 24,48 , and $72 \mathrm{~h}$ compared to the control cells (Fig. 2). These observations provided proof for cytotoxic nature of MEPA. Cytotoxicity of sorafenib tosylate was, however, much greater than MEPA (IC ${ }_{50}$ of $2.09 \mu \mathrm{g} / \mathrm{ml}$ ) [12-14]. The $\mathrm{IC}_{50}$ as calculated after MTT assay was $150.42 \mu \mathrm{g} / \mathrm{ml}$ for HepG2 cells. Another graph of MTT assay taking $1 / 2 \mathrm{IC}_{50}, \mathrm{IC}_{50}$ and $2 \mathrm{IC}_{50}$ doses for $24 \mathrm{~h}$ showed a dose-dependent decrease in $\mathrm{OD}$ at $570 \mathrm{~nm}$ (Fig. 2).

\section{DISCUSSION}

Preliminary phytochemical studies showed the presence of an ample amount of alkaloids. The observed cytotoxicity may be due to these phytoconstituents; alkaloids have historically been found to possess such properties. Therapeutically such cytotoxicity may be a constraint in the usage of MEPA for various in vivo ailments such as diabetes and wound healing activity. The dosage regimen and the duration of therapy are important parameters that may guide the researchers to balance between its beneficial and potential toxic properties. Since the study was carried out using whole MEPA, further isolation and characterization of the bioactive principles may provide potent molecules for targeting cancerous cells. Furthermore, from toxicological point of view, identification and separation of such principles may enhance the benefit: Risk ratio of the herbal drug.

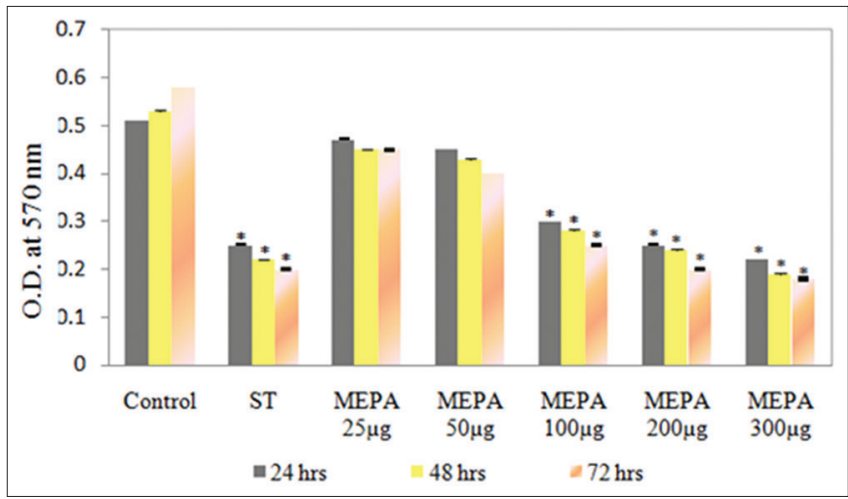

Fig. 1: Histogram shows the effect of MEPA on cell cytotoxicity by MTT assay on HepG2 cell lines after 24, 48, and $72 \mathrm{~h}$. The OD at $570 \mathrm{~nm}$ is compared to the untreated cells and sorafenib tosylate treated cells. Data expressed as mean \pm SEM. *Denotes significant decrease in OD at $570 \mathrm{~nm}$ from control values $\mathrm{p}<0.05$

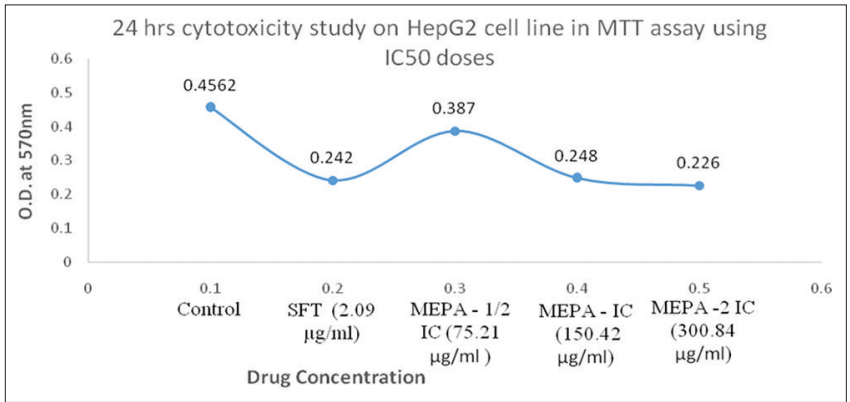

Fig. 2: The line diagram shows the effect of $1 \frac{1}{2} \mathrm{IC}_{50}, \mathrm{IC}_{50}$, and $2 \mathrm{IC}_{50}$ doses of MEPA on cell cytotoxicity by MTT assay on HepG2 cell lines after $24 \mathrm{~h}$. The $\mathrm{OD}$ at $570 \mathrm{~nm}$ is compared to the untreated cells and sorafenib tosylate treated cells. Data are expressed as mean \pm SEM

\section{CONCLUSION}

MEPA showed in vitro cytotoxicity in mammalian hepatic cells (HepG2) at a concentration as low as $100 \mu \mathrm{g}$. The potential to produce cytotoxicity may be a basis to use MEPA for treating hepatocarcinoma. However, the selectivity of MEPA toxicity toward cancerous tissues needs to be evaluated; else, the finding may also indicate potential damage of liver tissues of treated organisms, especially on repeated administration.

\section{ACKNOWLEDGMENT}

The authors are thankful to Mrs. Susmita Chakraborty, Chairman, Trinity Trust, Gupta College of Technological Sciences, Asansol, for providing the required facility to complete this work and constant motivation to achieve the goals.

\section{AUTHORS' CONTRIBUTIONS}

Bose S (SB) conceived, supervised, and guided the project. Datta $\mathrm{R}$ (RD) carried out the research work, including collection, extraction, and in vitro studies. Mandal SK (SKM) also supervised and guided the research work and prepared the manuscript.

\section{CONFLICTS OF INTEREST}

All authors report no conflicts of interest regarding this manuscript.

\section{AUTHORS' FUNDING}

The authors received no specific funding for this work 


\section{REFERENCES}

1. Pelkonen $\mathrm{O}, \mathrm{Xu}$ Q, Fan TP. Why is research on herbal medicinal products important and how can we improve its quality? J Tradit Complement Med 2004;4:1-7.

2. Chatterjee P, Chakraborty B, Dwivedi A, Datta R. Pterospermum acerifolium (L.) Willd: A comprehensive review with significant pharmacological activities. Int J Pharm Life Sci 2012;3:1153-8.

3. Basu KR, Basu BD. Indian Medicinal Plants. $2^{\text {nd }}$ ed. New Delhi: Bishen Singh Mahendra Pal Singh; 1987.

4. Van Meerloo J, Kaspers GJ, Cloos J. Cell sensitivity assays: The MTT assay. Methods Mol Biol 2011;731:237-45.

5. Wilkening S, Stahl F, Bader A. Comparison of primary human hepatocytes and hepatoma ell line HepG2 with regard to their biotransformation properties. Drug Metab Dispos 2003;31:1035-42.

6. Hewitt NJ, Lechón MJ, Houston JB, Hallifax D, Brown HS, Maurel P, et al. Primary hepatocytes: Current understanding of the regulation of metabolic enzymes and transporter proteins, and pharmaceutical practice for the use of hepatocytes in metabolism, enzyme induction, transporter, clearance, and hepatotoxicity studies. Drug Meta Rev 2007;39:159-234.

7. Sinz M, Kim S. Stem cells, immortalized cells and primary cells in
ADMET assays. Drug Discov Today Technol 2006;3:79-85.

8. Soldatow VY, Le Cluyse EL, Griffith LG, Rusynet I. In vitro models for liver toxicity testing. Toxicol Res 2013;2:23-39.

9. Rodrigues RM, De Kock J, Branson S, Vinken M, Meganathan K, Chaudhari U, et al. Human skin-derived stem cells as a novel cell source for in vitro hepatotoxicity screening of pharmaceuticals. Stem Cells Dev 2014;23:44-55.

10. Brechot C. Pathogenesis of hepatitis B virus-related hepatocellular carcinoma: Old and new paradigms. Gastroenterology 2004;127:S56-61.

11. Yu MC, Yuan JM. Environmental factors and risk for hepatocellular carcinoma. Gastroenterology 2004;127:S72-8.

12. Block TM, Mehta AS, Fimmel CJ, Jordan R. Molecular viral oncology of hepatocellular carcinoma. Oncogene 2003;22:5093-107.

13. Dey S, Roy S, Deb N, Sen KK, Besra SE, Anti-carcinogenic activity of Ruellia tuberosa L. (Acanthaceae) leaf extract on hepatoma cell line ande increased superoxide dismutase activity on macrophage cell lysate. Int J Pharm Pharm Sci 2013;5:854-61.

14. Carter CA, Chen C, Brink C, Vincent P, Maxuitenko YY, Gilbert KS, et al. Sorafenib is efficacious and tolerated in combination with cytotoxic or cytostatic agents in preclinical models of human non-small cell lung carcinoma. Cancer Chemoth Pharm 2007;59:183-95. 